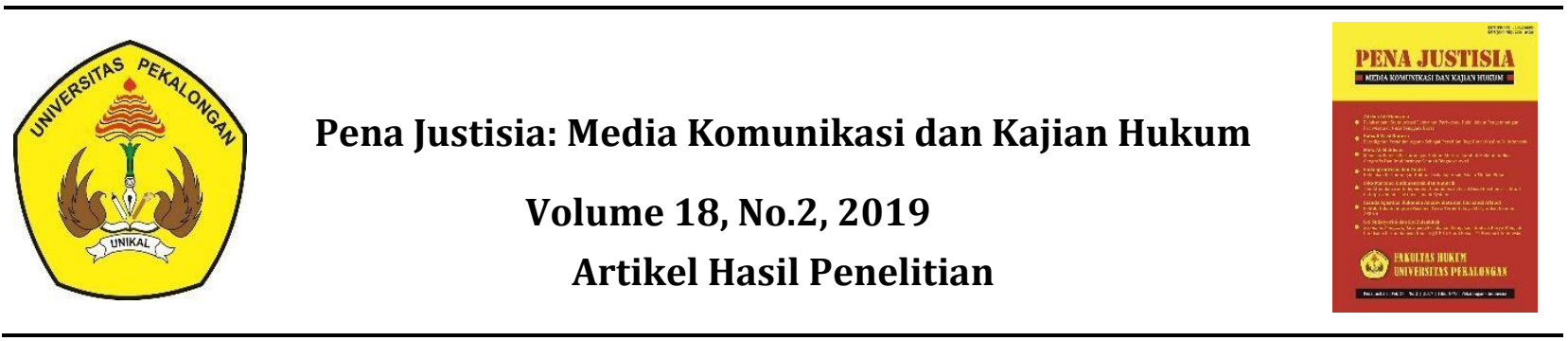

\title{
IMPLEMENTASI DALUARSA GUGATAN DALAM PUTUSAN PERADILAN TATA USAHA NEGARA DI INDONESIA
}

Keywords:

Case Expiry, Administrative Court and Decision

Kata kunci:

Daluarsa, Peradilan Tata Usaha Negara, Putusan.

\section{Abdul Kadir Jaelani}

Fakultas Hukum Universitas Sebelas Maret, Surakarta, Indonesia. E-mail: jaelaniabdulkadir@staff.uns.ac.id

\begin{tabular}{l}
\hline Info Artikel \\
\hline Keywords: \\
Case Expiry, Administrative \\
Court and Decision \\
Kata kunci: \\
Daluarsa, Peradilan Tata Usaha \\
Negara, Putusan.
\end{tabular}

\begin{tabular}{|c|}
\hline$c t$ \\
\hline $\begin{array}{l}\text { This study aims at describing the application of the expiry of the case in } \\
\text { Indonesia 's State Administrative Court ruling, the form of analysis used is } \\
\text { conventional legal investigation. This analysis is concise. The type of data } \\
\text { that is used is secondary. Secondary techniques of gathering data were } \\
\text { obtained through research into libraries. All primary and secondary data were } \\
\text { qualitatively analyzed. The findings showed that the Semarang State } \\
\text { Administrative Court Decision No. } 64 \text { / G/2014 / PTUN.SMG and the } \\
\text { Surabaya State Administrative Court Decision No. } 135 \text { / B/2015 / SBY did } \\
\text { not explore and analyze the Supreme Court Circular Letter Number } 2 \text { of } \\
1991 \text { concerning the Implementation Guidelines for Several Provisions in } \\
\text { Law Number } 5 \text { of } 1986 \text { concerning State Administrative Court, section V } \\
\text { number 3, Article } 39 \text { paragraph (1) and paragraph (2) of Law Number } 32 \\
\text { Year } 2009 \text { concerning Environmental Protection and Management and } \\
\text { Article } 9 \text { paragraph (1) jo Article } 4 \text { of Law No. } 14 \text { of } 2008 \text { concerning Public } \\
\text { Information Openness. }\end{array}$ \\
\hline Abstrak \\
\hline $\begin{array}{l}\text { Penelitian ini bertujuan untuk menjelaskan implementasi daluarsa gugatan dalam } \\
\text { putusan Peradilan Tata Usaha Negara di Indonesia, Jenis penelitian yang digunakan } \\
\text { adalah penelitian bukum normatif. Penelitian ini bersifat deskriptif. Jenis data yang } \\
\text { digunakan adalah data sekunder. Tekhnik. pengumpulan data sekunder diperoleh melalui } \\
\text { penelitian kepustakaan. Data primer dan sekunder dianalisis secara kualitatif. Hasil } \\
\text { penelitian menunjukean bahwa putusan Peradilan Tata Usaha Negara Semarang } \\
\text { Nomor 64/G/2014/PTUN.SMG dan Putusan Pengadilan Tinggi Tata Usaha } \\
\text { Negara Surabaya No. 135/B/2015/SBY kurang menggali dan menganalisa Surat } \\
\text { Edaran Mabkamah Agung Nomor } 2 \text { Tabun } 1991 \text { tentang Petunjuk. Pelaksanan } \\
\text { Beberapa Ketentuan Dalam Undang-Undang Nomor } 5 \text { Tabun } 1986 \text { tentang Peradilan } \\
\text { Tata Usaha Negara, bagian V angka 3, Pasal } 39 \text { ayat (1) dan ayat (2) UU Nomor } \\
32 \text { Tahun } 2009 \text { tentang Perlindungan dan Pengelolaan Lingkungan Hidup dan Pasal } \\
9 \text { ayat (1) jo Pasal4 UU No. } 14 \text { Tabun } 2008 \text { Tentang Keterbukaan Informasi Publik. }\end{array}$ \\
\hline
\end{tabular}

\section{PENDAHULUAN}

Upaya penegakan hukum lingkungan yang tepat, konsisten, dan berkelanjutan akan memberikan landasan kuat bagi terselenggaranya pembangunan, baik di bidang ekonomi, politik, sosial budaya, dan pertahanan keamanan. Penegakan hukum lingkungan sangat berkaitan erat dengan kebijakan lingkungan yang dikeluarkan oleh pemerintah, di mana 
terkadang ada kebijakan pemerintah yang keliru sehingga menimbulkan kontroversi dalam pelaksanaannya. ${ }^{1}$

Menurut David Trubeck, pembuatan dan penegakan hukum merupakan suatu "purposive human action". Dengan kata lain, pembuatan undang-undang tidak pernah bersifat otonom dan steril, melainkan sarat dengan kepentingan-kepentingan kelompok, atau kekuatan-kekuatan potensial dalam suatu negara yang menginginkan kepentingankepentingannya dilegalisasi atau diproteksi dalam undang-undang, karena undangundang menurut Schuyut merupakan "een neerlag van politieke machtsverhoudingngen" (suatu endapan dari pertukaran antara kekuatan-kekuatan politik dalam masyarakat) ${ }^{2}$ atau dalam pandangan Karl Marx disebutnya sebagai representasi dari kekuatankekuatan kapitalis. ${ }^{3}$ Harry Supriyono menjelaskan bahwa, krisis lingkungan hidup yang mendunia seperti sekarang ini setidaknya disebabkan oleh berbagai hal diantaranya: ${ }^{4}$

1. Kebijakan hukum yang salah dan gagal.

2. Teknologi yang tidak efisien bahkan cenderung merusak.

3. Rendahnya komitmen politik, gagasan, dan ideologi yang akhirnya merugikan lingkungan, tindakan.

4. Tingkah laku menyimpang dari aktor-aktor negara seperti korporasi transnasional, merebaknya pola kebudayaan seperti konsumerisme dan individualisme, serta individu-individu yang tidak terbimbing dengan baik.

Berbagai faktor di atas kemudian menyumbangkan krisis lingkungan dari berbagai segi, terutama di sektor kehutanan. Lingkungan hidup adalah kesatuan ruang dengan semua benda, daya, keadaan, dan makhluk hidup, termasuk manusia dan perilakunya, yang mempengaruhi alam itu sendiri, kelangsungan perikehidupan, dan kesejahteraan manusia serta makhluk hidup lain. ${ }^{5}$ Persoalan lingkungan hidup yang sering dibahas dalam beberapa tahun belakangan ini adalah persoalan PT. Semen Gresik (Persero) Tbk, mendapatkan Izin Lingkungan Kegiatan Penambangan dan Pembangunan Pabrik Semen melalui Surat Keputusan No. 660.1/17 Tahun 2012 tentang Izin Lingkungan Kegiatan Penambangan dan Pembangunan Pabrik Semen Oleh PT. Semen Gresik (Persero) Tbk. di Kabupaten Rembang, Provinsi Jawa Tengah tertanggal 7 Juni 2012. Keputusan tersebut memenuhi ketentuan Pasal 1 ayat (3) Undang-Undang Nomor 51 Tahun 2009, Keputusan Tata Usaha Negara yang dapat digugat di Peradilan Tata Usaha Negara, haruslah memenuhi syarat-syarat: 6

1) Bersifat tertulis, hal ini diperlukan untuk memudahkan pembuktian. Pengertian tertulis disini bukanlah dalam arti bentuk formalnya, melainkan cukup tertulis, asal saja:

a. Jelas Badan atau Pejabat Tata Usaha yang mengeluarkannya.

\footnotetext{
${ }^{1}$ Harry Supriyono, "Kajian Yuridis Sistem Penaatan dan Penegakan Hukum Lingkungan Administratif dalam Pengendalian Dampak Lingkungan", Disertasi, Program Doktor Ilmu Hukum Pascasarjana Fakultas Hukum Universitas Indonesia Tahun 2011, hlm. 1.

${ }^{2}$ Suparman Marzuki, 2011, Tragedi Politik Hukum HAM, Pustaka Pelajar, Yogyakarta, hlm. 12.

${ }^{3}$ A.A.G. Peters dan Koesriani Siswosoebroto, 1988, Hukum dan Perkembangan Sosial Buku Teks Sosiologi Hukum, Sinar Harapan, Jakarta, hlm.141.

${ }^{4}$ Harry Supriyono, "Kajian Yuridis Sistem Penaatan dan Penegakan Hukum Lingkungan Administratif dalam Pengendalian Dampak Lingkungan", Disertasi..., hlm. 3.

5Pasal 1 ayat (1) Undang-Undang No. 32 Tahun 2009 tentang Perlindungan dan Pengelolaan Lingkungan Hidup.

${ }^{6}$ Titik Triwulan dan Ismu Gunadi Widodo, 2011, Hukum Tata Usaha Negara dan Hukum Acara Peradilan Tata Usaha Negara Indonesia, Kencana Prenada Media Group, Jakarta, hlm.24.
} 
b. Jelas isi dan maksud tulisan tersebut yang menimbulkan hak dan kewajiban.

c. Jelas kepada siapa tulisan ini ditujukan.

2) Bersifat kongkrit, artinya obyek yang diputus dalam Keputusan Tata Usaha Negara itu berwujud tertentu atau dapat ditentukan.

3) Bersifat individual, artinya Keputusan Tata Usaha Negara itu tidak ditujukan untuk umum, tetapi ditujukan untuk orang-orang atau badan hukum perdata tertentu. Jadi tidak berupa suatu peraturan yang berlaku umum.

4) Bersifat final, artinya sudah definitif dan karenanya dapat menimbulkan akibat hukum, atau ketetapan yang tidak membutuhkan lagi persetujuan dari instansi atasannya.

Jika dicermati Surat Keputusan No. 660.1/17 Tahun 2012 tentang Izin Lingkungan Kegiatan Penambangan dan Pembangunan Pabrik Semen Oleh PT. Semen Gresik (Persero) Tbk. di Kabupaten Rembang, Provinsi Jawa Tengah melanggar ketentuan Pasal 53 ayat (2) huruf a dan b UU No. 5 Tahun 1986 Tentang Peradilan Tata Usaha Negara yang menyatakan:

a. Keputusan Tata Usaha Negara yang digugat itu bertentangan dengan peraturan perundang-undangan yang berlaku.....".

b. Keputusan Tata Usaha Negara yang digugat itu bertentangan dengan asas-asas pemerintahan yang baik......."

Berdasarkan ketentuan Pasal 53 ayat (2) huruf a PENGGUGAT mendalilkan bahwa Surat Keputusan a-quo bertentangan dengan peraturan perundang-undangan sebagai berikut: ${ }^{7}$

\begin{tabular}{|c|c|c|}
\hline No & Peraturan yang Bertentangan & Pokok Alasan \\
\hline 1 & $\begin{array}{l}\text { UU No. } 7 \text { Tahun } 2004 \text { Tentang } \\
\text { Sumber Daya Air jo Kepres No. } \\
26 \quad \text { Tahun } 2011 \text { Tentang } \\
\text { Penetapan Cekungan Air Tanah }\end{array}$ & $\begin{array}{l}\text { Konservasi sumber daya air dilaksanakan } \\
\text { salah satunya di cekungan air tanah; } \\
\text { cekungan Watu Putih sudah ditetapkan } \\
\text { sebagai cekungan air tanah }\end{array}$ \\
\hline 2 & $\begin{array}{l}\text { UU No. } 26 \text { Tahun } 2007 \\
\text { Tentang Penataan Ruang jo PP } \\
\text { No, 26 Tahun } 2008 \text { Tentang } \\
\text { Rencana Tata Ruang Wilayah } \\
\text { Nasional }\end{array}$ & $\begin{array}{l}\text { Bentang alam karts dan kawasan } \\
\text { imbuhan air tanah adalah kawasan lindung } \\
\text { geologi }\end{array}$ \\
\hline 3 & $\begin{array}{lrr}\text { UU No. } 32 \text { Tahun } & 2009 \\
\text { Tentang } & \text { Perlindungan } & \text { dan } \\
\text { Pengelolaan Lingkungan Hidup }\end{array}$ & $\begin{array}{l}\text { Keputusan a-quo mengandung cacat } \\
\text { hukum, kekeliruan, penyalahgunaan, serta } \\
\text { ketidakbenaran, dan/atau pemalsuan data, } \\
\text { dokumen, dan/atau informasi. }\end{array}$ \\
\hline 4 & $\begin{array}{l}\text { Perda Jawa Tengah No. } 6 \\
\text { Tahun } 2010 \text { Tentang Rencana } \\
\text { Tata Ruang Wilayah Provinsi } \\
\text { Jawa Tengah Tahun 2010-2030 } \\
\text { jo Kepres No. 26 Tahun } 2011 \\
\text { Tentang Penetapan Cekungan } \\
\text { Air Tanah }\end{array}$ & $\begin{array}{l}\text { Cekungan Watu Putih adalah kawasan } \\
\text { lindung imbuhan air yang seharusnya } \\
\text { dilindungi }\end{array}$ \\
\hline
\end{tabular}

7 Putusan perkara Nomor: 064/G/2014/PTUN.Smg, hlm. 28. 
5 Perda Kabupaten Rembang No. 14 Tahun 2011 Tentang RTRW Kabupaten Tahun 20112031 jo Kepres No. 26 Tahun 2011 Tentang Penetapan Cekungan Air Tanah
Cekungan Watu Putih adalah kawasan lindung imbuhan air yang seharusnya dilindungi

Luas konsesi melebihi kawasan yang diperuntukkan untuk industri pertambangan besar

Sedangkan berdasarkan ketentuan Pasal 53 ayat (2) huruf b PENGGUGAT mendalilkan bahwa Surat Keputusan a-quo bertentangan dengan asas-asas pemerintahan yang baik yang meliputi: asas kepastian hukum, asas tertib penyelenggaraan negara, asas kepentingan umum, asas keterbukaan, asas proporsionalitas, asas profesionalitas, dan asas akuntabilitas. ${ }^{8}$ Dengan demikian metode pembuatan AMDAL PT Semen Indonesia ini bertentangan dengan Peraturan Menteri Lingkungan Hidup Nomor 8 Tahun 2006 tentang Pedoman Penyusunan AMDAL. Bahwa konsekuensi atas perbedaan atau pertentangan metode analisis dalam AMDAL tersebut, menjadikan AMDAL PT Semen Indonesia tbk sesungguhnya tidak dapat digunakan sebagai persyaratan terbitnya Keputusana quo, SK Gubernur Jawa Tengah No 660.1/17/2012 tentang Izin Lingkungan Kegiatan Penambangan oleh PT Semen Indonesia (Persero) tbk di Kabupaten Rembang.

Keterangan ini juga dikuatkan oleh data yang dirilis oleh Perkumpulan HuMA Indonesia, Jakarta, dkk. yang menerangkan bobroknya AMDAL yang dijadikan dasar mengeluar KTUN a-quo oleh Gubernur Jawa Tengah. Berikut dipaparkan rilis data boleh HuMA Indonesia, Jakarta, dkk.: ${ }^{9}$

\begin{tabular}{|c|c|c|c|c|}
\hline No & Nama & $\begin{array}{c}\text { Amdal PT. } \\
\text { Semen Indonesia }\end{array}$ & $\begin{array}{c}\text { Fakta di } \\
\text { Lapangan }\end{array}$ & Keterangan \\
\hline 1 & Goa & 9 buah & 64 buah & $\begin{array}{l}\text { - } 5 \text { buah Goa di dalam dan di garis } \\
\text { IUP } \\
\text { - Di cek tahun } 2014 \text { sampai } \\
\text { sekarang masih ada }\end{array}$ \\
\hline 2 & Ponor & - & 28 buah & $\begin{array}{l}\text { - } 8 \text { buah panor berada di dalam dan } \\
\text { di garis IUP } \\
\text { - Di cek tahun } 2014 \text { sampai } \\
\text { sekarang masih ada }\end{array}$ \\
\hline 3 & $\begin{array}{l}\text { Mata } \\
\text { Air }\end{array}$ & 40 buah & 125 buah & $\begin{array}{l}\text { - } 5 \text { mata air berada di dalam dan di } \\
\text { garis IUP } \\
\text { - Di cek tahun } 2014 \text { sampai } \\
\text { sekarang masih ada }\end{array}$ \\
\hline
\end{tabular}

Selain itu ditemukan fakta-fakta sebagai berikut:

1. Pada dokumen ANDAL PT. Semen Indonesia halaman V-80 nomor 4 disebutkan Goa Menggah dalamnya $115 \mathrm{~m}$ dan kering. Padahal fakta di lapangan adalah goa basah dan ada aliran sungai bawah tanah dengan kedalaman 20 m;

\footnotetext{
${ }^{8}$ Putusan perkara Nomor: 064/G/2014/PTUN.Smg, hlm. 28-29.

${ }^{9}$ HuMA Indonesia, Jakarta, dkk. Tanpa tahun, Amicis Curiae Peninjanan Kembali Putusan PTUN Semarang Nomor: 064/G/2014/PTUN.SMG dan Putusan PT TUN Surabaya Nomor: 135/B/2015/PT.TUN.SBY. hlm. 29-30.
} 
2. Pada Dokumen ANDAL halaman III - 20 berdasarkan penelitian Dinas Energi dan Pertambangan Kabupaten Rembang (1998) dengan mengacu grafik hubungan antara daerah imbuhan, imbuhan air tanah tahunan, dan rata-rata luahan mata air, maka imbuhan air tanah tahunan sebesar $230 \mathrm{~mm}$ dapat diketahui daerah imbuhan air sumber semen $635 \mathrm{~L}$ /detik seluas 7.500 ha sedangkan mata air Brubulan tahunan (100 L/detik) seluas 20 ha. Data ini tidak benar mengingat pada tahun 1998 di Kabupaten Rembang belum ada Dinas ESDM;

3. Penyusunan AMDAL PT Semen Indonesia tidak menggunakan prakiraan besar dampak dengan pendekatan selisih with and without sebagaimana disyaratkan dalam Peraturan Menteri Lingkungan Hidup Nomor 08 Tahun 2006 tentang Pedoman Penyusunan AMDAL, tetapi penyusun AMDAL menggunakan metode before and after yang mengakibatkan AMDAL TIDAK SAH DAN TIDAK VALID.

Berdasarkan uraian di atas dapat diambil kesimpulan bahwa Hakim Tata Usaha Negara adalah pejabat yang berwenang memeriksa, memutus dan menyelesaikan sengketa Tata Usaha Negara di dalam lingkungan PTUN. Secara umum memang kewenangan hakim adalah memeriksa, memutus, dan menyelesaikan sengketa. Menurut Pasal 1 angka 10 Undang-Undang Nomor 51 Tahun 2009 tentang Peradilan Tata Usaha Negara menyebutkan, Sengketa Tata Usaha Negara adalah sengketa yang timbul dalam bidang tata usaha negara antara orang atau badan hukum perdata dengan badan atau pejabat Tata Usaha Negara, baik di pusat maupun di daerah, sebagai akibat dikeluarkannya keputusan tata usaha negara, termasuk sengketa kepegawaian berdasarkan peraturan perundang-undangan yang berlaku. ${ }^{10}$

\section{PEMBAHASAN}

\section{Kompetensi/Kewenangan Peradilan Tata Usaha Negara}

Kompetensi Peradilan Tata Usaha Negara menurut Undang-Undang Nomor 51 Tahun 2009 jauh lebih sempit lagi, karena tidak semua perkara yang pokok sengketanya terletak di lapangan Hukum Publik (Hukum Tata Usaha Negara) dapat diadili di Peradilan Tata Usaha Negara. Menurut ketentuan pasal 1 ayat (3) Undang-Undang Nomor 51 Tahun 2009, Keputusan Tata Usaha Negara yang dapat digugat di Peradilan Tata Usaha Negara, haruslah memenuhi syarat-syarat: ${ }^{11}$

1) Bersifat tertulis, hal ini diperlukan untuk memudahkan pembuktian.

2) Bersifat kongkrit, artinya obyek yang diputus dalam Keputusan Tata Usaha Negara itu berwujud tertentu atau dapat ditentukan.

3) Bersifat individual, artinya Keputusan Tata Usaha Negara itu tidak ditujukan untuk umum, tetapi ditujukan untuk orang-orang atau badan hukum perdata tertentu. Jadi tidak berupa suatu peraturan yang berlaku umum.

4) Bersifat final, artinya sudah definitif dan karenanya dapat menimbulkan akibat hukum, atau ketetapan yang tidak membutuhkan lagi persetujuan dari instansi atasannya

\footnotetext{
${ }^{10}$ Udiyo Basuki, 2013, Pedoman Beracara Peradilan Tata Usaha Negara, SUKA PRESS, Yogyakarta, hlm.7.

${ }^{11}$ Titik Triwulan dan Ismu Gunadi Widodo, 2011, Hukum Tata Usaha Negara dan Hukum Acara Peradilan Tata Usaha Negara Indonesia, Kencana Prenada Media Group, Jakarta, hlm.24.
} 
Di samping mengadili pada tingkat pertama sengketa Tata Usaha Negara sebagaimana dimaksud dalam pasal 48 Undang-Undang Nomor 5 Tahun 1986, Pengadilan Tinggi Tata usaha Negara juga berwenang: ${ }^{12}$

1. Memeriksa dan memutus sengketa Tata Usaha Negara di tingkat Banding.

2. Memeriksa dan memutus di tingkat pertama dan terakhir sengketa kewenangan mengadili antara Pengadilan Tata Usaha Negara di dalam daerah hukumnya.

Kewenangan Pengadilan untuk menerima, memeriksa, memutus menyelesaikan perkara yang diajukan kepadanya yang dikenal dengan kompetensi atau kewenangan mengadili. PTUN mempunyai kompetensi menyelesaikan sengketa tata usaha negara di tingkat pertama. Sedangkan Pengadilan Tinggi Tata Usaha Negara (PT.TUN) untuk tingkat banding. Akan tetapi untuk sengketa-sengketa tata usaha negara yang harus diselesaikan terlebih dahulu melalui upaya administrasi berdasarkan Pasal 48 UndangUndang Nomor 51 tahun 2009 perubahan Undang-Undang Nomor 5 tahun 1986. Dalam pasal 48 Undang-Undang No.5 Tahun 1986 jo Undang-Undang No.51 Tahun 2009 tentang Peradilan Tata Usaha Negara, disebutkan sebagai

berikut :

1. Dalam hal suatu Badan/Pejabat Tata Usaha Negara diberi wewenang oleh atau berdasarkan peraturan perundang-undangan untuk menyelesaikan secara administratif sengketa Tata Usaha Negara tertentu, maka sengketa Tata Usaha Negara tersebut harus diselesaikan melalui upaya administratif yang tersedia.

2. Pengadilan baru berwenang memeriksa, memutus, dan menyelesaikan sengketa Tata Usaha Negara sebagaimana dimaksud ayat (1) jika seluruh upaya administratif yang bersangkutan telah digunakan.

Ada beberapa cara untuk mengetahui kompetensi dari suatu pengadilan untuk memeriksa, mengadili dan memutus suatu perkara: pertama, dapat dilihat dari pokok sengketanya (geschilpunt, fundamentum petendi), kedua, dengan melakukan pembedaan atas atribusi (absolute competentie atau attributie van rechtsmacht) dan delegasi (relatieve competentie atau distributie van distributie van rechtsmacht), ketiga, dengan melakukan pembedaan atas kompetensi absolut dan kompetensi relatif. ${ }^{13}$ Pertama, dilihat dari pokok sengketanya, apabila pokok sengketanya terletak dalam lapangan hukum privat, maka sudah tentu yang berkompetensi adalah hakim biasa (hakim pengadilan umum). Apabila pokok sengketanya terletak dalam lapangan hukum publik, maka sudah tentu yang berkompetensi adalah administrasi negara yang berkuasa (hakim PTUN). Kedua, dengan melakukan pembedaan atas kewenangan mengadili dengan pembagian kompetensi atas atribusi (absolute competentie atau attributie van rechtsmacht) dan delegasi (relatieve competentie atau distributie van rechtsmacht) dapat dijelaskan sebagai berikut:

1. Atribusi, yang berkaitan dengan pemberian wewenang yang bersifat bulat (absolut) mengenai materinya, yang dapat dibedakan:

a) Secara horizontal, yaitu wewenang yang bersifat bulat dan melekat dari suatu jenis pengadilan terhadap jenis pengadilan lainnya, yang mempunyai kedudukan sederajat/ setingkat. Contoh: Pengadilan Administrasi

${ }^{12} \mathrm{Ibid}, \mathrm{hlm} .26$.

13Zairin Harahap, 1999, Hukum Acara Peradilan Tata Usaha Negara, PT. Raja Grafindo Persada, Jakarta, hlm. 28. 
terhadap Pengadilan Negeri (umum), Pengadilan Agama atau Pengadilan Militer.

b) Secara vertical, yaitu wewenang yang bersifat bulat dan melekat dari suatu jenis pengadilan lainnya, yang secara berjenjang atau hirarki mempunyai kedudukan lebih tinggi. Contoh: Pengadilan Negeri (umum) terhadap Pengadilan Tinggi dan Mahkamah Agung.

2. Distribusi, yang berkaitan dengan pembagian wewenang yang bersifat terinci (relatif) di antara badan-badan yang sejenis mengenai wilayah hukum. Contoh; antara Pengadilan Negeri Yogyakarta dengan Pengadilan Negeri antara lain di Bantul, Sleman dan Kulonporogo.

Ketiga, adalah pembagian atas kompetensi absolut dan kompetensi relatif. Kompetensi absolut adalah menyangkut kewenangan badan peradilan apa yang memeriksa, mengadili, dan memutus suatu perkara. Kompetensi dari Peradilan Tata Usaha Negara adalah untuk memeriksa, mengadili dan memutuskan sengketa yang timbul dalam bidang tata usaha negara akibat dikeluarkannya suatu keputusan tata usaha negara, termasuk sengketa kepegawaian dan tidak dikeluarkannya suatu keputusan yang dimohonkan seseorang sampai batas waktu yang ditentukan dalam suatu peraturan perundang-undangan, sedangkan hal itu telah merupakan kewajiban badan atau pejabat tata usaha negara yang bersangkutan. Kompetensi relatif, adalah kewenangan dari pengadilan sejenis, yang mana yang berwenang untuk memeriksa, mengadili, dan memutus perkara yang bersangkutan. Dalam kaitannya dengan Peradilan Tata Usaha Negara, maka kompetensi relatifnya adalah menyangkut kewenangan peradilan tata usaha negara yang mana yang berwenang untuk memeriksa, mengadili, dan memutus perkara tersebut. Apakah PTUN Ujung Pandang, Surabaya, Semarang, Bandung, Jakarta, Palembang, atau Medan, dan sebagainya. ${ }^{14}$ Berkaitan dengan kompetensi PTUN tersebut di atas, dalam pasal 77 UU PTUN disebutkan:

1. Eksepsi tentang kewenangan absolut pengadilan dapat diajukan setiap waktu selama pemeriksaan, dan meskipun tidak ada eksepsi tentang kewenangan absolut pengadilan apabila hakim mengetahui hal itu, ia karena jabatannya wajib menyatakan bahwa pengadilan tidak berwenang mengadili sengketa yang bersangkutan.

2. Eksepsi tentang kewenangan relatif pengadilan diajukan sebelum disampaikan jawaban atas pokok sengketa, dan eksepsi tersebut harus diputus sebelum pokok sengketa diperiksa.

3. Eksepsi lain yang tidak mengenai kewenangan pengadilan hanya dapatdiputus bersama dengan pokok sengketa.

Dengan demikian, eksepsi terhadap kompetensi relatif dari PTUN, harus disampaikan tergugat sebelum memberikan jawaban atas pokok sengketa, apabila eksepsi itu disampaikan setelah memberikan jawaban atas pokok sengketa, maka eksepsi tersebut tidak lagi dapat diterima. Keberadaan Peradilan Tata Usaha Negara bukan untuk mencaricari kesalahan, apalagi mengurangi kewibawaan Badan atau Pejabat Tata Usaha Negara, tetapi justru sebaliknya agar terbinanya aparatur yang mampu menjadi alat yang efisien, efektif, bersih dan berwibawa dan selalu berdasarkan hukum serta bersih dari kolusi, korupsi dan nepotisme juga dilandasi semangat serta sikap pengabdian untuk masyarakat di dalam menjalankannya tugasnya. Di lain pihak juga tindakan yang tidak

${ }^{14}$ Ibid, hlm.30 
tepat dari Badan atau Pejabat Tata Usaha Negara. Oleh karenanya Peradilan Tata Usaha Negara dibentuk untuk menyelesaikan sengketa yang timbul dalam bidang tata usaha negara antara orang atau badan hukum privat dengan Badan atau Pejabat Tata Usaha Negara sebagai akibat dikeluarkannya Keputusan Tata Usaha Negara akibat pelaksanaan atau penggunaan wewenang pemerintahan yang dilakukan oleh Badan/Pejabat Tata Usaha Negara yang menimbulkan benturan kepentingan, perselisihan, atau sengketa dengan warga masyarakat atau badan hukum privat, atau sengketa dengan warga masyarakat atauu badan hukum privat dengan Badan atau Pejabat Tata Usaha Negara.

Tujuan dari Peradilan Tata Usaha Negara adalah untuk mengembangkan dan memelihara administrasi negara yang tepat menurut hukum, atau tepat menurut Undang-Undang, ataupun tepat secara efektif maupun berfungsi secara efisien. Faktor terpenting untuk mendukung efektifitas peranan pemerintah adalah faktor makna kontrol Yudisial dengan spesifikasi karakteristiknya. Hal tersebut, mendasari konsepsi mengenai Peradilan Tata Usaha Negara yang merupakan pelembagaan kontrol yudisial terhadap tindakan pemerintah. Pembentukan Peradilan Tata Usaha Negara di Indonesia tidak akan mencontoh belaka pada sistem Peradilan Tata Usaha Negara di Negara lain. Akan tetapi disesuaikan dengan kebutuhan situasi dan kondisi serta perkembangan di Indonesia, bahkan akan diciptakan sistem sendiri yang sesuai dengan kebut uhan dan keadaan di Indonesia yang berfalsafah Pancasila. ${ }^{15}$

\section{Sengketa dan Keputusan Tata Usaha Negara}

Pasal 1 angka (10) Undang-Undang Nomor 51 Tahun 2009 menyebutkan, Sengketa Tata Usaha Negara adalah sengketa yang timbul dalam bidang Tata Usaha Negara antara orang atau badan hukum perdata dengan badan atau pejabat Tata Usaha Negara, baik di pusat maupun di daerah, sebagai akibat di keluarkannya Keputusan Tata Usaha Negara, termasuk sengketa kepegawaian berdasarkan peraturan perundang-undangan yang berlaku. Mengacu pada rumusan di atas, dapat disimpulkan bahwa unsur-unsur sengketa Tata Usaha Negara terdiri dari:

1. Subyek yang bersengketa adalah orang atau badan hukum privat di satu pihak dan Badan atau Pejabat Tata Usaha Negara di lain pihak.

2. Obyek sengketa adalah keputusan yang dikeluarkan oleh Badan atau Pejabat Tata Usaha Negara

Sebagai Jabatan TUN yang memiliki kewenangan pemerintah, sehingga dapat menjadi pihak yang tergugat dalam sengketa TUN dapat dikelompokkan dalam : 16

1. Instansi resmi pemerintah yang berada di bawah presiden sebagai kepala eksekutif.

2. Instansi-instansi dalam lingkungan kekuasaan negara di luar lingkungan eksekutif yang berdasarkan peraturan perundang-undangan, melaksanakan suatu urusan pemerintahan.

3. Badan-badan hukum privat yang didirikan dengan maksud untuk melaksanakan tugas-tugas pemerintahan.

15Victor S, Soedibyo, 1992, Pokok-Pokok, Peradilan Tata Usaha Negara, PT. Rineka Cipta, Jakarta, hlm. 11.

16A.Siti Soetami, 2007, Hukum Acara Peradilan Tata Usaha Negara, Refika Aditama, Bandung, hlm. 5. 
4. Instansi -instansi yang merupakan kerja sama antara pemerintahan dan pihak swasta yang melaksanakan tugas-tugas pemerintahan.

5. Lembaga-lembaga hukum swasta yang melaksanakan tugas-tugas pemerintahan.

Obyek sengketa TUN adalah keputusan yang dikeluarkan oleh badan atau Pejabat Tata Usaha Negara. Keputusan Tata Usaha Negara adalah suatu penetapan tertulis yang dikeluarkan Badan atau Pejabat Tata Usaha Negara yang berisi tindakan hukum Tata Usaha Negara berdasarkan peraturan perundang-undangan yang berlaku, yang bersifat konkrit, individual dan final, yang menimbulkan akibat hukum bagi seseorang atau badan hukum perdata. Jenis-jenis Keputusan Tata Usaha Negara/ KTUN (Beschikking) menurut doktrin (pendapat/ teori para pakar administrasi Negara) terdapat berbagai rumusan, antara lain menurut P.De Haan (Belanda), dalam bukunya: "Bestuursrecht in de Sociale Rechtsstaat", dikelompokkan sebagai berikut:17

1. KTUN Perorangan dan Kebendaan (Persoonlijk en Zakelijk)

a. KTUN perorangan adalah keputusan yang diterbitkan kepada seseorang berdasarkan kualitas pribadi tertentu, dimana hak yang timbul tidak dapat dialihkan kepada orang lain. Contoh : SK PNS, SIM,dan sebagainya.

b. KTUN kebendaan adalah keputusan yang diterbitkan berdasarkan kualitas kebendaan atau status suatu benda sebagai obyek hak, dimana hak yang timbul dapat dialihkan kepada orang lain. Contoh : Sertifikat Hak atas Tanah, BPKP/STNK kendaraan bermotor, dan sebagainya

2. KTUN Deklaratif dan Konstitutif (Rechtsvastellend en Rechtsscheppend)

a. KTUN deklaratif adalah keputusan yang sifatnya menyatakan atau menegaskan adanya hubungan hukum yang secara riil sudah ada. Contoh : Akta Kelahiran, Akta Kematian, dan sebagainya.

b. KTUN konstitutif adalah keputusan yang menciptakan hubungan hukum baru yang sebelumnya tidak ada, atau sebaliknya memutuskan hubungan hukum yang ada. Contoh : Akta Perkawinan, Akta Perceraian, dan sebagainya.

3. KTUN Bebas dan Terikat (Vrij en Gebonden)

KTUN bebas adalah keputusan yang didasarkan atas kebebasan bertindak (Freis Ermessen/ Discretionary Power) dan memberikan kebebasan bagi pelaksananya untuk melakukan penafsiran atau kebijaksanaan. Contoh: SK Pemberhentian PNS yang didasarkan hukuman disiplin yang telah diatur secara jelas dan rinci di dalam perundang-undangan.

4. KTUN yang membebankan dan yang menguntungkan (Belastend en Begunstigend)

a. KTUN yang member beban adalah keputusan yang memberikan kewajiban. Contoh : SK tentang Pajak, Restribusi, dan lain-lain.

b. KTUN yang menguntungkan adalah keputusan yang memberikan keuntungan bagi pihak yang dituju. Contoh : SK pemutihan pembayaran pajak yang telah kadaluwarsa.

5. KTUN Seketika dan Permanen (Einmaligh en Voortdurend)

\footnotetext{
${ }^{17}$ Ujang Abdullah, "Kompetensi Peradilan Tata Usaha Negara dalam Sistem Peradilan di Indonesia", artikel $\begin{array}{llllll}\text { diakses } & \text { pada } & 10 & \text { Februari } & 2017 & \text { dari }\end{array}$ http:/ / www.ptun.palembang.go.id/index.php?option=com_content\&task=view\&id=575\&Itemid=294.
} 
a. KTUN seketika adalah keputusan yang masa berlakunya hanya sekali pakai. Contoh: Surat ijin pertunjkan hiburan, music, olahraga, dll

b. KTUN pemanen adalah keputusan yang masa berlakunya untuk selamalamanya, kecuali ada perubahan atau peraturan baru. Contoh: Sertifikat Hak Milik

Undang-Undang Nomor 51 tahun 2009 tentang Perubahan Kedua Atas UndangUndang Nomor 5 tahun 1986 tentang Peradilan Tata Usaha Negara:

1) Keputusan Tata Usaha Negara Positif (Pasal 1 angka (3)) Yaitu penetapan tertulis yang dikeluarkan oleh Badan/Pejabat Tata Usaha Negara yang berisi tindakan hukum Tata Usaha Negara yang berdasarkan peraturan perundangundangan yang berlaku, bersifat konkrit, individual dan final yang menimbulkan akibat hukum bagi seseorang atau Badan Hukum Perdata.

2) Keputusan Tata Usaha Negara Fiktif (Pasal 3 angka (1)) Yaitu keputusan Tata Usaha Negara yang seharusnya dikeluarkan oleh Badan/Pejabat Tata Usaha Negara menurut kewajibannya tetapi ternyata tidak diterbitkan, sehingga menimbulkan kerugian bagi seseorang atau Badan Hukum Perdata. Contoh : Dalam kasus kepegawaian, seorang atasan berkewajiban membuat DP3 atau mengusulkan kenaikan pangkat bawahannya, tetapi atasannya tidak melakukan.

3) Keputusan Tata Usaha Negara Fiktif Negatif (Pasal 3 ayat (2)) Yaitu keputusan Tata Usaha Negara yang dimohonkan seseorang atau Badan Hukum Perdata, tetapi tidak ditanggapi atau tidak diterbitkan oleh Badan/Pejabat Tata Usaha Negara yang bersangkutan. Sehingga dianggap bahwa Badan/Pejabat Tata Usaha Negara telah mengeluarkan keputusan penolakan (negatif). Contoh : Pemohon IMB, KTP, Sertifikat, dan sebagainya apabila dalam jangka waktu yang ditentukan tidak dijawab/diterbitkan, maka dianggap jelas-jelas menerbitkan keputusan Tata Usaha Negara yang menolak.

\section{Daluarsa Surat Gugatan (Putusan PTUN Semarang Nomor 64/G/2014/PTUN.SMG dan Putusan PT TUN Surabaya No. 135/B/2015/SBY)}

Majelis hakim PTUN Semarang dan PT TUN Surabaya KELIRU dalam menghitung tenggang waktu daluarsa ( 90 hari) dalam pengajuan surat gugatan ke PTUN Semarang. Perhitungan tenggang waktu daluarsa tersebut hendaknya memperhatikan saat pertamakali penggugat mengetahui "secara patut" Surat Keputusan Gubernur Jawa Tengah No 660.1/17/2012 tentang Izin Lingkungan Kegiatan Penambangan oleh PT Semen Gresik (Persero) tbk di Kabupaten Rembang. Secara patut dalam kasus tersebut, berkaitan dengan tiga dasar hukum: Pertama, SEMA No. 2 Tahun 1991 tentang Petunjuk Pelaksanaan Beberapa Ketentuan Dalam UU No. 5 Tahun 1986 Tentang Peradilan Tata Usaha Negara, bagian V angka 3. Kedua, Pasal 39 ayat (1) dan ayat (2) UU No. 32 Tahun 2009 tentang Perlindungan dan Pengelolaan Lingkungan Hidup. Ketiga, Pasal 9 ayat (1) jo Pasal 4 UU No. 14 Tahun 2008 Tentang Keterbukaan Informasi Publik.

Daluwarsa atau sering juga disebut dengan lewat waktu (verjaring) merupakan istilah yang sudah tidak asing di dalam dunia hukum. Dalam Hukum Tata Usaha Negara daluwarsa juga diatur di dalam Pasal 55 UU No. 51 Tahun 2009 Tentang Perubahan Kedua Atas UU No. 5 Tahun 1986 tentang Peradilan Tata Usaha Negara, namun Pasal 55 ini hanya berlaku bagi pihak yang namanya tersebut dalam KTUN. Pasal 55 menyatakan: 
"Gugatan dapat diajukan hanya dalam tenggang waktu sembilan puluh hari terhitung sejak saat diterimanya atau diumumkannya Keputusan Badan atau Pejabat Tata Usaha Negara."

Sementara untuk pihak yang namanya tidak tersebut dalam KTUN (dalam hal ini penggugat dalam perkara $a$-quo), maksud dari penghitungan 90 (sembilan puluh) hari, Mahkamah Agung telah menerbitkan SEMA No. 2 Tahun 1991 tentang Petunjuk Pelaksanaan Beberapa Ketentuan Dalam Undang-undang Nomor 5 Tahun 1986 Tentang Peradilan Tata Usaha Negara, bagian V angka 3, menyebutkan bahwa:

"Bagi mereka yang tidak dituju oleh suatu Keputusan Tata Usaha Negara tetapi yang merasa kepentingannya dirugikan maka tenggang waktu sebagaimana dimaksud dalam Pasal 55 dihitung secara kasuistis sejak saat ia merasa kepentingannya dirugikan oleh Keputusan Tata Usaha Negara dan mengetahui adanya Keputusan tersebut."

Hal ini dikuatkan oleh yurisprudensi Mahkamah Agung dalam Putusan No. 1/1994/PK dalam perkara Jalan Sabang Jakarta, yang pada intinya menyatakan bahwa bagi pihak atau orang yang tidak dituju secara langsung tenggang waktu 90 hari dihitung secara kasuistis, yaitu sejak kapan pihak ke-3 merasakan kepentingannya dirugikan oleh Surat Keputusan objek sengketa a quo secara resmi menurut hukum. Yurisprudensi ini merupakan penjelasan lebih lanjut dari SEMA No. 2 Tahun 1991 pada bagian V angka 3 yang merumuskan bahwa bagi mereka yang tidak dituju oleh suatu Keputusan TUN, tetapi yang merasakan kepentingannya dirugikan, maka tenggang waktu sebagaimana dimaksud Pasal 55 dihitung secara kasuistis sejak saat ia merasakan kepentingannya dirugikan oleh KTUN yang mengetahui adanya keputusan tersebut. Hal ini juga dikuatkan oleh Zairin Harahap yang menyatakan "bagi mereka yang tidak dituju secara lansung oleh KTUN, namun merasa kepentingannya dirugikan, maka perhitungan 90 hari mulai dihitung sejak ia mengetahui adanya KTUN tersebut"18 Selain itu, karena keputusan a quo sangat berkaitan dengan persoalan lingkungan hidup, maka hakim juga tidak bisa melepaskan diri dari ketentuan lingkungan hidup dalam menentukan daluarsanya suatu surat gugatan. UU No. 32 Tahun 2009 tentang Perlindungan dan Pengelolaan Lingkungan Hidup telah menggariskan kewajiban yang harus dilakukan oleh pegambil kebijakan sebelum dan setelah megeluarkan keputusan dan inilah yang kemudian harus diperhatikan hakim. Pasal 39 Ayat (1) UU No. 32 Tahun 2009 tentang Perlindungan dan Pengelolaan Lingkungan Hidup menyatakan bahwa Menteri, Gubernur, Bupati/Walikota sesuai dengan kewenangannya wajib mengumumkan permohonan dan keputusan izin lingkungan.

Pasal 39 ayat (2) UU Nomor 32 Tahun 2009 tentang Perlindungan dan Pengelolaan Lingkungan Hidup menyatakan bahwa pengumuman sebagaimana dimaksud pada ayat (1) dilakukan dengan cara yang mudah diketahui oleh masyarakat. Dalam bagian penjelasan Pasal 39 Ayat (1) UU Nomor 32 Tahun 2009 tentang Perlindungan dan Pengelolaan Lingkungan Hidup dinyatakan bahwa pengumuman dalam Pasal ini merupakan pelaksanaan atas keterbukaan informasi. Pengumuman tersebut memungkinkan peran serta masyarakat, khususnya yang belum menggunakan kesempatan dalam prosedur keberatan, dengar pendapat, dan lain-lain dalam proses pengambilan keputusan izin.

18Zairin Harahap, 2015, Hukum Acara Peradilan Tata Usaha Negara, Rajawali Pers, Jakarta, hlm.119. 
Sementara UU No. 14 Tahun 2008 Tentang Keterbukaan Informasi Publik khususnya Pasal 4 dan Pasal 9 ayat (1), selain menyatakan "melihat, mengetahui, dan memperoleh informasi merupakan hak dari setiap warga negara", ketentuan tersebut juga memberikan amanat kepada badan publik (negara) untuk mengumumkan informasi publik yang bersifat berkala kepada masyarakat dan informasi tersebut disampaikan kepada masyarakat dengan cara yang mudah dijangkau oleh masyarakat. Tidak hanya itu, cara menyampaikannya pun harus menggunakan bahasa yang mudah dimengerti, karena setiap individu mempunyai daya jelajah pemahaman yang berbeda-beda. Apabila badan publik tidak menjalankan asas-asas keterbukaan informasi publik seperti yang dijelaskan di atas, maka potensi munculnya konflik horizontal dan vertikal akan besar, apalagi terkait dengan informasi yang menyangkut hajat orang banyak. Seperti diketahui, rencana pembangunan Pabrik Semen di Kabupaten Rembang merupakan kebijakan yang menyangkut hajat orang banyak, karena terkait dengan "penggusuran" lahan warga dan juga eksploitasi alam yang berdampak pada kerusakan alam. Sehingga, negara (dalam hal ini Pemerintah Kabupaten Rembang dan Pemerintah Provinsi Jawa Tengah) harus membuka segala informasi yang terkait dengan pembangunan dan perencanaannya kepada masyarakat luas, terutama masyarakat yang tinggal di daerah proyek yakni masyarakat Pegunungan Kendeng.

Namun, dalam kenyataannya SK Gubernur Jawa Tengah No 660.1/17/2012 tentang Izin Lingkungan Kegiatan Penambangan oleh PT Semen Indonesia (Persero) tbk di Kabupaten Rembang tersebut memang telah diumumkan oleh Kepala Badan Lingkungan Hidup (BLH) Jawa Tengah dengan surat bernomor 660.1/BLH.II/0960 pada tanggal 12 Juni 2012 di Balai Desa, Kantor Kecamatan, dan di Lokasi Rencana Kegiatan. Tapi ternyata para penggugat dan warga Rembang lainnya yang pada umumnya berprofesi sebagai petani ini tidak setiap hari bisa menyempatkan diri pergi ke ketiga tempat itu untuk secara mudah mengetahui pengumuman tersebut, sehingga mereka bisa berperan dalam menggunakan kesempatan dalam prosedur keberatan, dengar pendapat, dan lain-lain dalam proses pengambilan keputusan izin seperti yang disebuatkan di bagian Penjelasan Pasal 39 Ayat 1 UU Nomor 32 Tahun 2009 tentang Perlindungan dan Pengelolaan Lingkungan Hidup.

Bahwa begitu pula halnya dengan pengumuman melalui website, Judex Factie menganggap para Penggugat telah mengetahui KTUN Objek Sengketa. Kesimpulan Judex Factie ini jelas-jelas tidak mempertimbangkan fakta bahwasanya teknologi website belum bisa diakses oleh seluruh warga Rembang yang terkena dampak. Di sisi lain, warga Rembang memiliki tradisi lokal terkait dengan bagaimana informasi harus disampaikan ke warga, yakni melalui woro-woro yang dilakukan oleh Bayan (perangkat Desa) secara berkeliling Desa untuk menyampaikan informasi. Itu sebabnya seorang warga Rembang, yakni Baskoro Budhi Dharmawan (warga Rembang) pada 5 Juni 2014 mengajukan permohonan informasi perihal Kegiatan Penambangan oleh PT Semen Indonesia (Persero) tbk di Kabupaten Rembang tersebut ke BLH Jateng, dan baru pada 18 Juni 2014 ia mendapat jawaban dari BLH Jateng. Di jawaban itulah Baskoro memperoleh informasi tentang telah terbitnya SK Gubernur Jateng tentang Izin Lingkungan Kegiatan Penambangan oleh PT Semen Indonesia tbk di Rembang itu. Jawaban tersebut kemudian ia informasikan ke para penggugat.

Sehingga, sekalipun KTUN yang menjadi Objek Sengketa dikeluarkan di Semarang pada tanggal 7 Juni 2012, namun Para Penggugat secara kasuistis baru mengetahui dan mendapatkan KTUN Objek Sengketa adalah pada 18 Juni 2014 setelah Baskoro Budhi 
Darmawan memperoleh informasi tersebut pada tanggal 18 Juni 2014 yang kemudian memberitahukannya kepada Para Penggugat. Maka patut diduga, bahwa sebelum 18 Juni 2014 para penggugat ini hanya ikut menentang AMDAL Pabrik Semen Indonesia yang mereka anggap dibuat secara keliru dan merugikan mereka. Mereka sama sekali tidak mengetahui SK Gubernur Jateng tersebut. Argumentasi Judex Factie secara prematur membuat kesimpulan bahwa kalau masyarakat protes dan keberatan masyarakat pasti mengetahui Surat Keputusan Gubernur Jawa Tengah No 660.1/17/2012 tentang Izin Lingkungan Kegiatan Penambangan oleh PT Semen Gresik (Persero) tbk di Kabupaten Rembang. Padahal menurut keterangan para penggugat dan saksi-saksi, mereka melakukan protes, bukan karena mengetahui SK tersebut, melainkan setelah melihat alat berat perusahaan mulai didatangkan. Seharusnya majelis hakim lebih peka dan berupaya menggali keterangan dari mereka tentang mengapa mereka tak pernah mengetahui pengumuman yang ditempel di Balai Desa dan Kantor Kecamatan itu.

Setelah menghitung secara cermat, sejak kapan para Penggugat mengetahui Surat Keputusan Gubernur Jawa Tengah No 660.1/17/2012 tentang Izin Lingkungan Kegiatan Penambangan oleh PT Semen Gresik (Persero) tbk di Kabupaten Rembang itu, maka tenggang waktu gugatan yang mereka ajukan ke PTUN Semarang pada 1 September 2014 itu sebenarnya adalah masuk pada hari ke-75 (tujuh puluh lima), bukan lebih dari 90 (sembilan puluh) hari. Karena itu, menegaskan bahwa gugatan mereka belum kadaluarsa dan tidak tepat secara hukum dinyatakan “... Gugatan Para Penggugat Tidak Diterima (Niet Onvakelijke Verklaard).” oleh Majelis Hakim PTUN Semarang.

Penting dan mendasar sifatnya agar Majelis Hakim PTUN lebih mengedepankan pertimbangan hukum terkait tujuan pengumuman dibandingkan semata soal prosedur formal penyampaian pengumuman. Dalam kerangka hukum lingkungan, jelaslah bahwa tujuan pengumuman ini adalah agar hak masyarakat atas informasi terpenuhi. Hak atas informasi itu adalah salah satu pilar pelaksanaan asas tata kelola pemerintahan yang baik dalam perlindungan dan pengelolaan lingkungan hidup (Pasal 2 huruf $m$ UU No. 32 Tahun 2009 tentang Perlindungan dan Pengelolaan Lingkungan Hidup). Selain itu, penting sebagai pembelajaran hukum publik, bahwa partisipasi adalah hak, yang merupakan hak asasi manusia yang telah diakui dalam sistem hukum nasional, sebagai hak yang memiliki konstitusionalitas (vide: Pasal 28F UUD 1945).

Atas dasar itu, berpandangan bahwa Putusan PTUN Semarang dan PT TUN Surabaya tersebut secara jelas KELIRU menghitung tenggang waktu daluarsa gugatan $a$-quo. Selain itu, kami berpandangan hakim dalam menilai putusan tidaklah bersungguh-sungguh dalam menggali alasan secara lebih baik untuk memahami ketidaktahuan warga Rembang yang hadir sebagai Penggugat. Hal ini tentu bertentangan dengan kewajiban hakim yang diatur dalam Kode Etik Profesi Hakim yang menyatakan, "Bersungguh-sungguh mencari kebenaran dan keadilan."

\section{PENUTUP}

Berdsarkan pembahasan di atas maka dapat disimpulkan bahwa pertama, Obyek sengketa TUN adalah keputusan yang dikeluarkan oleh badan atau Pejabat Tata Usaha Negara. Keputusan Tata Usaha Negara adalah suatu penetapan tertulis yang dikeluarkan Badan atau Pejabat Tata Usaha Negara yang berisi tindakan hukum Tata Usaha Negara berdasarkan peraturan perundang-undangan yang berlaku, yang bersifat konkrit, individual dan final, yang menimbulkan akibat hukum bagi seseorang atau badan hukum perdata. Kedua, Putusan PTUN Semarang dan PT TUN Surabaya tersebut secara jelas 
keliru menghitung tenggang waktu daluarsa gugatan a-quo. Selain itu, kami berpandangan hakim dalam menilai putusan tidaklah bersungguh-sungguh dalam menggali alasan secara lebih baik untuk memahami ketidaktahuan warga Rembang yang hadir sebagai Penggugat. Hal ini tentu bertentangan dengan kewajiban hakim yang diatur dalam Kode Etik Profesi Hakim yang menyatakan, "Bersungguh-sungguh mencari kebenaran dan keadilan."

\section{REFERENCES}

A.A.G. Peters dan Koesriani Siswosoebroto, 1988, Hukum dan Perkembangan Sosial Buku Teks Sosiologi Hukum, Sinar Harapan, Jakarta.

A.Siti Soetami, 2007, Hukum Acara Peradilan Tata Usaha Negara, Refika Aditama, Bandung.

Harry Supriyono, "Kajian Yuridis Sistem Penaatan dan Penegakan Hukum Lingkungan Administratif dalam Pengendalian Dampak Lingkungan", Disertasi, Program Doktor Ilmu Hukum Pascasarjana Fakultas Hukum Universitas Indonesia Tahun 2011.

Muchsan, 2016, Materi Kuliah Politik Hukum, Program Studi Magister Hukum Pada Tanggal 17 Februari 2017 di Ruang Guru Besar Fakultas Hukum Universitas Gadjah Mada.

Lego Karjoko, Zaidah Nur Rosidah, I Gusti Ayu Ketut Rahmi Handayani, "Refleksi Paradigma Ilmu Pengetahuan Bagi Pembangunan Hukum Pengadaan Tanah”, Jurnal Bestuur, Volume 7, Nomor 1 Tahun 2019.

I Gusti Ayu Ketut Rahmi Handayani, Lego Karjoko, Abdul Kadir Jaelani, "Model Pelaksanaan Putusan Mahkamah Konstitusi yang Eksekutabilitas Dalam Pengujian Peraturan PerundangUndangan di Indonesia", Jurnal Bestuur, Volume 7, Nomor 1 Tahun 2019.

Ivnaini Andesgur, "Analisa Kebijakan Hukum Lingkungan dalam Pengelolaan Pestisida", Jurnal Bestuur, Volume 7, Nomor 2 Tahun 2019.

Udiyo Basuki, Abdul Kadir Jaelani, "Problematika Pelaksanaan Putusan Mahkamah Konstitusi Nomor 100/PUU-XI/2013 Dalam Mendudukkan Pancasila Sebagai Dasar Negara”, Wacana Hukum, Vol. 24, Nomor 2 Tahun 2019.

Putusan perkara Nomor: 064/G/2014/PTUN.Smg.

Putusan perkara Nomor: 064/G/2014/PTUN.Smg.

Suparman Marzuki, 2011, Tragedi Politik Hukum HAM, Pustaka Pelajar, Yogyakarta.

Titik Triwulan dan Ismu Gunadi Widodo, 2011, Hukum Tata Usaha Negara dan Hukum Acara Peradilan Tata Usaha Negara Indonesia, Kencana Prenada Media Group, Jakarta.

Udiyo Basuki, 2013, Pedoman Beracara Peradilan Tata Usaba Negara, SUKA PRESS, Yogyakarta.

Ujang Abdullah, "Kompetensi Peradilan Tata Usaha Negara dalam Sistem Peradilan di Indonesia", artikel diakses pada $10 \quad$ Februari 2017 dari http:/ / www.ptun.palembang.go.id/index.php?option=com_content\&task=view\&id $=575 \&$ Itemid=29Zairin Harahap, 2015, Hukum Acara Peradilan Tata Usaha Negara, Rajawali Pers, Jakarta.

Undang-Undang No. 32 Tahun 2009 tentang Perlindungan dan Pengelolaan Lingkungan Hidup. Victor S, Soedibyo, 1992, Pokok-Pokok Peradilan Tata Usaha Negara, PT. Rineka Cipta, Jakarta. Victor Imanual W. Nalle, 2013, Konsep Uji Materiil: Kajian Pembentukan dan Uji Materiil Peraturan Kebijakan di Indonesia, Setara Press, Malang.

Zairin Harahap, 1999, Hukum Acara Peradilan Tata Usaha Negara, PT. Raja Grafindo Persada, Jakarta.

Lego Karjoko, Zaidah Nur Rosidah, I Gusti Ayu Ketut Rahmi Handayani, "Refleksi Paradigma Ilmu Pengetahuan Bagi Pembangunan Hukum Pengadaan Tanah", Jurnal Bestuur, Volume 7, Nomor 1 Tahun 2019. 
I Gusti Ayu Ketut Rahmi Handayani, Lego Karjoko, Abdul Kadir Jaelani, "Model Pelaksanaan Putusan Mahkamah Konstitusi yang Eksekutabilitas Dalam Pengujian Peraturan PerundangUndangan di Indonesia", Jurnal Bestuur, Volume 7, Nomor 1 Tahun 2019.

Ivnaini Andesgur, "Analisa Kebijakan Hukum Lingkungan dalam Pengelolaan Pestisida”, Jurnal Bestuur, Volume 7, Nomor 2 Tahun 2019.

Udiyo Basuki, Abdul Kadir Jaelani, "Problematika Pelaksanaan Putusan Mahkamah Konstitusi Nomor 100/PUU-XI/2013 Dalam Mendudukkan Pancasila Sebagai Dasar Negara", Wacana Hukum, Vol. 24, Nomor 2 Tahun 2019. 